\title{
PENGARUH MODEL PEMBELAJARAN INKUIRI TERBIMBING BERBASIS EKSPERIMEN RIIL DAN LABORATORIUM VIRTUAL TERHADAP HASIL BELAJAR FISIKA SISWA
}

\section{EFFECTS OF GUIDED INQUIRY LEARNING MODEL BASED REAL EXPERIMENTS AND VIRTUAL LABORATORY TOWARDS THE RESULTS OF STUDENTS' PHYSICS LEARNING}

\author{
Dedi Holden Simbolon \\ Universitas Sutomo \\ Jl. Sutomo Ujung No.28D, Medan Tim., Kota Medan \\ e-mail: dediholdensimbolon@gmail.com \\ Sahyar \\ Pascasarjana Universitas Negeri Medan (UNIMED) \\ JI. Willem Iskandar Psr. V Medan, Sumatera Utara
}

Naskah diterima tanggal: 08/05/2015, Direvisi akhir tanggal: 30/10/2015, disetujui tanggal: 10/12/2015

\begin{abstract}
This study aims to analyze the difference of learning outcomes between students who were taught physics using guided inquiry-based learning model experiments with real and virtual laboratory learning model compare to Instruction Direct Instruction (DI). This study was a quasi-experimental. The study population was students of class XI-IPA Methodist 1 High School Medan of the school year 2012/2013. Sampling technique using a cluster random sampling consisting of two classes with a total sample of 76 students. The data analysis performed by Two Way Anova. The results obtained that there are significant difference between the results of studying physics students taught using guided inquiry learning model based on real and virtual laboratory experimentation and students taught using direct learning model. It can be concluded that the Guided Inquiry learning model based on real and virtual laboratory experiments is better than direct instructional model in improving student learning outcomes physics. There is a significant interaction between guided inquiry learning model based on real and virtual laboratory experiments and direct instructional model regarding the level of activity of the physics students' learning outcomes.
\end{abstract}

Keywords: Guided Inquiry, Direct Instruction, Virtual Laboratory, Real Experiment

\footnotetext{
Abstrak: Penelitian ini bertujuan untuk menganalisis perbedaan antara hasil belajar fisika siswa yang diajar dengan menggunakan model pembelajaran inkuiri terbimbing berbasis eksperimen riil dan laboratorium virtual dibandingkan dengan model pembelajaran Direct Instrusction (DI). Penelitian ini bersifat eksperimen semu (quasi experiment). Populasi penelitian adalah siswa kelas XI-IPA SMA Methodist 1 Medan tahun pelajaran 2012/ 2013.Teknik pengambilan sampel dengan menggunakan cluster random sampling yang terdiri atas dua kelas dengan jumlah sampel seluruhnya 76 orang siswa. Teknik analisis data yang digunakan adalah analisis variansi dua arah. Hasil penelitian yang diperoleh bahwa terdapat perbedaan yang signifikan antara hasil belajar fisika siswa yang diajar dengan menggunakan model pembelajaran inkuiri terbimbing berbasis eksperimen riil dan laboratorium virtual dibandingkan dengan siswa yang diajar dengan menggunakan model pembelajaran langsung (Direct Instruction). Dari hasil ini, dapat disimpulkan bahwa model pembelajaran Inkuiri Terbimbing berbasis eksperimen riil dan laboratorium virtual lebih baik dari pada model pembelajaran langsung (Direct Instruction) dalam meningkatkan hasil
} 
belajar fisika siswa. Ada interaksi yang signifikan antara model pembelajaran inkuiri terbimbing berbasis eksperimen riil dan laboratorium virtual dengan model pembelajaran langsung (Direct Instruction) dengan tingkat aktivitas terhadap hasil belajar fisika siswa.

Kata kunci: Inkuiri Terbimbing, pembelajaran langsung, Laboratorium Virtual, Eksperimen Riil

\section{PENDAHULUAN}

Perkembangan ilmu pengetahuan dan teknologi (IPTEK) memengaruhi hampir seluruh kehidupan manusia di berbagai bidang. Untuk dapat menguasai ilmu pengetahuan dan teknologi, maka kualitas sumber daya manusia harus ditingkatkan melalui peningkatan mutu pelajaran di sekolah. Pendidikan tidak hanya bertujuan memberikan materi pelajaran saja, tetapi menekankan bagaimana mengajak siswa untuk menemukan dan membangun pengetahuannya sendiri sehingga siswa dapat mengembangkan kecakapan hidup (life skill) dan siap untuk memecahkan masalah yang dihadapi dalam kehidupan.

Pendidikan bukanlah sesuatu yang statis melainkan sesuatu yang dinamis sehingga menuntut adanya suatu perbaikan yang terus menerus. Dunia pendidikan memiliki tujuan yang harus dicapai dalam proses pembelajarannya. Pendidikan tidak hanya ditekankan pada penguasaan materi, tetapi juga ditekankan pada penguasaan keterampilan. Siswa juga harus memiliki kemampuan untuk berbuat sesuatu dengan menggunakan proses dan prinsip keilmuan yang telah dikuasai, dan learning to know (pembelajaran untuk tahu) dan learning to do (pembelajaran untuk berbuat) harus dicapai dalam kegiatan belajar mengajar (Ambarsari, Santosa, dan Mariadi, 2013).

Dalam KTSP untuk pendidikan dasar dan menengah disebutkan bahwa sains berfungsi untuk mengembangkan keterampilan wawasan dan kesadaran teknologi dalam kaitan dengan pemanfaatannya bagi kehidupan sehari-hari. Melalui pembelajaran sains di sekolah, semestinya dapat digunakan untuk membentuk kemampuan manusia yang utuh, dalam arti mempunyai sikap, kemampuan kognitif, dan keterampilan memecahkan permasalahan yang dihadapi. Sesuai dengan Peraturan Pemerintah Nomor 19 tahun 2005 Pasal 25 (4) tentang Standar Nasional Pendidikan dijelaskan bahwa kompetensi lulusan mencakup sikap, pengetahuan, dan keterampilan (Kemdiknas, 2007). Ini berarti bahwa pembelajaran dan penilaian harus mengembangkan kompetensi siswa yang berhubungan dengan ranah afektif (sikap), kognitif (pengetahuan), dan psikomotor (keterampilan) (Prihatiningtyas, Prastowo, dan Jatmiko, 2013).

Kegiatan pembelajaran yang berlangsung di kelas masih menitikberatkan peran guru sebagai pemeran utama dalam proses pembelajaran. Guru juga masih mengutamakan ketuntasan materi dan kurang mengoptimalkan aktivitas belajar siswa. Siswa hanya menerima informasi yang diberikan oleh guru, sehingga partisipasi aktif dalam pembelajaran kurang terlihat. Hal tersebutlah yang mengakibatkan pembelajaran hanya terfokus pada kegiatan menghafal konsep, sehingga penguasaan konsep siswa rendah khususnya kemampuan dalam menyelesaikan suatu permasalahan. Kurang terlatihnya kemampuan pemecahan masalah akan membuat siswa merasa kesulitan untuk memahami konsep fisika. Hal ini dapat mengakibatkan penurunan hasil belajar siswa.

Guru dengan kompetensi yang dimilikinya diharapkan mampu memilih model pembelajaran yang tepat agar dapat mencapai tujuan pembelajaran yang telah ditentukan serta mencapai hasil belajar yang lebih optimal. Semua itu menuntut lingkungan belajar yang kaya dan nyata (rich and natural environment) agar dapat memberikan pengalaman belajar yang bermakna dan akhirnya dapat meningkatkan aktivitas dan hasil belajar siswa. Mengajar bukan 
sekedar usaha untuk menyampaikan ilmu pengetahuan, melainkan juga usaha untuk menciptakan sistem lingkungan yang membelajarkan siswa agar tujuan pengajaran dapat tercapai secara optimal (Gulo dalam Kristianti 2012).

Mengajar dalam pemahaman seperti ini memerlukan suatu model yang tepat bagi tujuan yang ingin dicapai, terutama dalam upaya mengembangkan aktivitas dan hasil belajar siswa. Untuk itu perlu dibina dan dikembangkan kemampuan professional guru untuk mengelola program pengajaran dengan strategi belajar yang kaya dengan variatif. Sesuai dengan yang tertera dalam Standar Kompetensi dan Kompetensi Dasar SMA, pembelajaran fisika di sekolah memiliki tujuan yaitu siswa dapat mengembangkan kemampuan penalaran induktif dan deduktif, menguasai konsep dan prinsip untuk mendeskripsikan berbagai peristiwa alam dan menyelesaikan masalah baik secara kualitatif maupun kuantitatif.

Dalam proses pembelajaran banyak komponen yang mempengaruhi hasil belajar, antara lain: tujuan, bahan atau materi yang dipelajari, strategi pembelajaran, siswa dan guru sebagai subjek belajar, media pembelajaran dan penunjang proses pembelajaran (Praptiwi, Sarwi, dan Handayani, 2012). Komponen-komponen tersebut saling terkait satu sama lain sehingga melemahnya satu komponen akan menghambat pencapaian tujuan pembelajaran secara maksimal. Pandangan lain tentang pembelajaran dengan pendekatan inkuiri yaitu dapat melibatkan siswa secara aktif menggunakan proses sains dan kemampuan kecakapan ilmiah dan kreatif seperti mereka menemukan jawaban atas pertanyaan-pertanyaan yang diajukan (Kristianti, 2012).

Keberhasilan siswa menyerap informasi dan pengetahuan dapat ditentukan oleh keaktifan siswa selama proses belajar mengajar dan transfer pengetahuan tidak lagi berorientasi pada guru tetapi pada keterlibatan aktif siswa pada saat proses belajar mengajar. Guru tidak lagi berperan sebagai aktor tetapi lebih sebagai fasilitator. Kegiatan belajar lebih menekankan siswa yang aktif sehingga proses pembelajaran berlangsung efektif. Seorang guru fisika mempunyai tugas untuk membuat kondisi pembelajaran yang menarik, menyenangkan yaitu kondisi pembelajaran yang demokratis, dapat membangkitkan siswa berani menyampaikan pendapat dan mampu menghubungkan materi pelajaran dengan kehidupan sehari-hari. Dengan kondisi pembelajaran yang seperti itu, diharapkan siswa senang terhadap pelajaran fisika, sehingga tidak lagi menganggap fisika itu sulit dan musuh bagi kalangan siswa pada saat mendapat pelajaran fisika, dengan demikian prestasi belajar atau hasil belajar juga akan semakin meningkat. Hasil belajar bukan hanya berupa penguasaan pengetahuan, tetapi juga kecakapan dan keterampilan dalam melihat, menganalisis, dan memecahkan masalah, membuat rencana dan mengadakan pembagian kerja. Dengan demikian, aktivitas dan produk yang dihasilkan dari ativitas belajar ini mendapatkan penilaian (Ambarsari, dkk, 2013). Salah satu metode pembelajaran yang mampu memfasilitasi tercapainya penguasaan konsep dan aktivitas siswa serta kemampuan pemecahan masalah siswa adalah metode eksperimen. Metode eksperimen merupakan metode pembelajaran yang dapat memberikan pengalaman langsung kepada siswa untuk memperkenalkan, membiasakan, dan melatihkan siswa untuk melaksanakan langkah-langkah ilmiah dan pengetahuan prosedural. Selain untuk menguasai konsep, praktikum juga berdampak positif terhadap peningkatan motivasi dan minat siswa (Rustaman, 2005). Penggunaan metode eksperimen dalam penelitian ini diterapkan dalam model pembelajaran inkuiri terbimbing. Metode eksperimen paling tepat untuk merealisasikan model pembelajaran inkuiri atau model pembelajaran berdasarkan penemuan. Berdasarkan penjelasan di atas, dapat diprediksi bahwa model pembelajaran inkuiri dengan menggunakan metode eksperimen mampu 
memfasilitasi penguasaan konsep dan aktivitas siswa yang berdampak pada prestasi belajar siswa.

Seiring berjalannya waktu, teknologi informasi yang mengalami perkembangan cukup pesat, yang menawarkan beberapa alternatif untuk melaksanakan kegiatan pembelajaran, seperti pembelajaran berbasis web, animasi, powerpoint, multimedia interaktif online dan offline dan masih banyak cara lain yang dapat mendukung dan memudahkan proses belajar mengajar di kelas. Pemanfaatan komputer sebagai salah satu media pembelajaran dihapakan dapat mengatasi keterbatasan ruang dan waktu, sehingga proses belajar mengajar dapat berjalan secara efektif dan efisien. Di samping itu, penggunaan komputer dapat dapat menjadi alternatif, ketika peralatan laboratorium kurang memadai. Dalam pelaksanaan pembelajaran, dengan bantuan komputer, siswa secara langsung berinteraksi dengan komputer yang telah dilengkapi dengan beberapa software pembelajaran yang berisi simulasi virtual. Melalui simulasi tersebut siswa dibimbing untuk menemukan kesimpulan akan materi yang sedang dipelajari.

Dalam penelitian ini, laboratorium virtual menggunakan konsep yang kedua, yaitu eksperimen yang dilakukan dengan menggunakan simulasi komputer, karena eksperimen tidak dikontrol langsung oleh peralatan laboratorium. Laboratorium virtual dapat diakses dengan mudah melalui internet dan dapat dipergunakan untuk mengantisipasi laboratorium riil yang belum memadai dan efisien untuk mencapai tujuan pembelajaran selama waktu yang singkat dengan biaya yang lebih murah. Selain itu laboratorium virtual juga menggabungkan sumber daya teknologi dengan software yang dapat digunakan kembali dan bersifat otomatis sesuai dengan konsep pelatihan yang benar serta dapat dikirim ke siapa saja, di mana saja dan kapan saja. Secara umum penggunaan laboratorium virtual dalam pembelajaran terus berkembang terutama dalam kajian penelitian. Berdasarkan hasil penelitian, penggunaan laboratorium virtual dalam pembelajaran berdampak positif terhadap peningkatan penguasaan konsep, kemampuan pemecahan masalah, kemampuan berfikir kritis, dan aktivitas siswa. Laboratorium sekolah sejatinya adalah unit penunjang akademik yang digunakan sebagai tempat pengujian, kalibrasi, dan produksi berdasarkan metode keilmuan tertentu dalam rangka melaksanakan pendidikan (Putri, Syakbaniah, dan Yulkifli, 2013). Pemanfaatan laboratorium virtual dalam proses pembelajaran menjadikan proses pembelajaran tersebut lebih efektif dari segi waktu dan meningkatkan prestasi belajar siswa (Tatli dan Ayas, 2013).

Dalam penelitian Prasetyo (2011) menyatakan bahwa adanya metode demonstrasi virtual dapat meningkatkan hasil belajar, tetapi tidak ada pengaruh antara tinggi rendahnya kemampuan awal dengan hasil belajar siswa. Penelitian yang dilakukan Sudarmi (2009) menghasilkan kesimpulan prestasi belajar siswa dengan pembelajaran inkuiri terbimbing dengan media laboratorium riil lebih tinggi dengan menggunakan laboratorium virtual tetapi prestasi belajar antara siswa yang memiliki gaya belajar kinestetik tidak berbeda dengan siswa yang memiliki gaya belajar visual. Penelitian Iswari (2009) menghasilkan kesimpulan prestasi belajar menggunakan media laboratorium riil lebih tinggi dibandingkan dengan laboratorium virtual dan siswa yang memiliki sikap ilmiah tinggi prestasi belajarnya juga lebih tinggi dari pada siswa yang memiliki sikap ilmiah rendah. Penelitian yang sudah dilakukan oleh Tarno (2010) menyimpulkan bahwa prestasi belajar yang menggunkan media laboratorium riil lebih tinggi daripada menggunakan laboratorium virtual. Penelitian Tarno ini menggunakan variabel moderator kemampuan berpikir dan kreativitas. Kedua variabel ternyata tidak memengaruhi prestasi belajar. Penelitian yang dilakukan Demirdag (2008) menyatakan bahwa metode Computer Aaided Education (CAE) memberikan efek yang lebih pada keberhasilan belajar kimia siswa, sikap terhadap kimia dan komputer dibandingkan dengan cara tradisional. Penelitian 
Dedi Holden Simbolon \& Sahyar, Pengaruh Model Pembelajaran Inkuiri Terbimbing Berbasis Eksperimen Riil Dan Laboratorium Virtual terhadap Hasil Belajar Fisika Siswa

oleh Gerald, Harol, dan Mike (2008) menyimpulkan siswa yang belajar dengan menggunakan laboratorium virtual lebih interaktif dibandingkan dengan kelas tradisional dan prestasi belajar Fisika di kelas tradisional lebih tinggi sedikit dibandingkan dengan kelas laboratorium virtual.

Berdasarkan penjelasan tersebut digunakan model pembelajaran Inkuiri Terbimbing, karena selain model ini cocok dipadukan dengan media praktikum atau eksperimen, model ini juga cocok bagi siswa, sehingga dapat meningkatakan hasil belajar fisikanya.

\section{KAJIAN LITERATUR}

\section{Model Pembelajaran Inkuiri Terbimbing}

Model pembelajaran dapat didefinisikan sebagai suatu pola mengajar yang menerangkan proses menyebutkan dan menghasilkan situasi lingkungan tertentu yang menyebabkan para siswa berinteraksi dengan cara terjadinya perubahan khusus pada tingkah laku, dengan kata lain penciptaan suatu situasi lingkungan yang memungkinkan terjadinya proses belajar mengajar. Inkuiri berdasarkan uraian sebelumnya adalah suatu proses bertanya dan mencari tahu jawaban terhadap pertanyaan ilmiah yang diajukannya untuk memperoleh dan mendapatkan informasi dengan menggunakan kemampuan berpikir kritis dan logis melalui kegiatan ilmiah.

Secara umum dapat disimpulkan bahwa model pembelajaran inkuiri merupakan model pembelajaran yang berpusat pada siswa (student centered) guru memberikan kesempatan seluas-luasnya kepada siswa untuk menemukan dan menyelidiki konsep yang dipelajarinya melalui kegiatan eksperimen guna menjawab pertanyaan-pertanyaan yang muncul dari dalam diri siswa mengenai masalah yang diberikan, penyelesaian dari masalah tersebut diselidiki dan ditemukan sendiri sesuai dengan kemampuannya. Sejalan dengan Piaget, yang mendefinisikan model pembelajaran inkuiri merupakan pembelajaran yang mempersiapkan situasi bagi siswa untuk melakukan eksperimen, dalam artian ingin melihat apa yang terjadi, ingin melakukan sesuatu, ingin menggunakan simbolsimbol dan ingin mencari jawaban atas pertanyaan sendiri, menghubungkan penemuan yang satu dengan yang lain, membandingkan apa yang ditemukan sendiri dengan apa yang di temukan yang lain.

Penerapan model pembelajaran inkuiri sangat berkaitan dengan teori belajar konstruktivisme yang berkembang atas dasar psikologi perkembangan kognitif dari Jean Piaget dan teori scaffolding (penyediaan dukungan untuk belajar dan memecahkan masalah) dari Lev Vygotsky (Dahar, 2011). Kedua ahli tersebut menyatakan perubahan kognitif seseorang hanya akan terjadi jika konsep awalnya mengalami proses ketidakseimbangan dengan adanya informasi baru. Titik berat teori konstruktivisme adalah gagasan bahwa siswa harus membangun pengetahuannya sendiri. Dengan belajar melalui inkuiri siswa akan terlibat dalam proses mereorganisasi struktur pengetahuannya melalui penggabungan konsepkonsep yang sudah dimiliki sebelumnya dengan ide-ide yang baru didapatkan. Dalam inkuiri, siswa dimotivasi untuk terlibat langsung atau berperan aktif secara fisik dan mental dalam kegiatan pembelajaran. Lingkungan kelas di mana siswa aktif terlibat dan guru berperan sebagai fasilitator pembelajaran sangat membantu dalam mencapai tujuan belajar.

Dampak pembelajaran dan dampak pengiring dari model pembelajaran inkuiri adalah: (1) Dapat mengembangkan keterampilan proses sains, (2) Model penyelidikan dapat dikembangkan secara kreatif, (3) Menimbulkan semangat kreatif dan semangat belajar pada siswa, (4) Memberikan kebebasan atau belajar secara otonomi pada siswa, (5) Memungkinkan kerjasama dua arah (guru-siswa dan siswa-siswa), (6) Menekankan hakekat kesementaraan dari pengetahuan.

Joyce dan Weil (2000) mengemukakan bahwa model pembelajaran berbasis inkuiri suatu proses melatih siswa untuk menginvestigasi dan menjelaskan fenomena yang tidak biasa. Pembelajaran inkuiri didesain sedemikian rupa agar siswa secara langsung 
yang melakukan proses ilmiah melalui latihan dalam waktu singkat. Sclenker (dalam Dahar, 2011) melaporkan bahwa pembelajaran inkuiri dapat menghasilkan peningkatan pemahaman sains, produktivitas, berfikir kreatif, serta siswa menjadi terampil dalam memperoleh dan menganalisis informasi.

Kelebihan model pembelajaran inkuiri yaitu (1) Model pengajaran menjadi berubah dari yang bersifat penyajian informasi menjadi pengolahan informasi, (2) Pengajaran berubah dari teacher centered menjadi student centered. Guru lebih banyak bersifat membimbing, (3) Dapat membentuk dan mengembangkan self-concept pada diri siswa, (4) Dapat memperkaya dan memperdalam materi yang dipelajari sehingga tahan lama dalam ingatan, (5) Memungkinkan siswa belajar dengan memanfaatkan berbagai jenis sumber belajar yang tidak hanya menjadikan guru sebagai satu-satunya sumber belajar, (6) Menghindarkan cara belajar tradisional (menghafal).

Kekurangan model pembelajaran inkuiri yaitu (1) Memerlukan perubahan kebiasaan cara belajar siswa yang menerima informasi dari guru apa danya menjadi belajar mandiri dan kelompok dengan mencari dan mengolah informasi sendiri. Mengubah kebiasaan bukanlah suatu hal yang mudah, apalagi kebiasaan yang telah bertahuntahun; (2) Guru dituntut mengubah kemasan mengajar yang umumnya sebagai penyaji informasi menjadi fasilitator dan motivator. Hal ini merupakan pekerjaan yang tidak gampang, karena umumnya guru merasa belum mengajar dan belum puas apabila tidak menyampaikan informasi (ceramah); (3) Metode ini dalam pelaksanaannya memerlukan penyediaan sumber belajar dan fasilitas yang memadai yang tidak selalu tersedia, (4) Metode ini tidak efisien khususnya untuk mengajar siswa dalam jumlah besar, sedangkan jumlah guru terbatas.

Peran guru dalam inkuiri terbimbing dalam memecahkan masalah yang diberikan kepada siswa adalah dengan memberikan pertanyaanpertanyaan dalam proses penemuan sehingga siswa tidak akan kebingungan. Sehingga kesimpulan akanlebih cepat dan mudah diambil. Guru bertindak sebagai penunjuk jalan, membantusiswa agar menggunakan ide, konsep, dan keterampilan yang sudah mereka pelajari sebelumnya untuk mendapatkan pengetahuan yang baru. Pengajuan pertanyaan yang tepat oleh guru akan merangsang kreativitas siswa dan membantu mereka dalam 'menemukan' pengetahuan baru tersebut. Model pembelajaran inkuiri terbimbing memang memerlukan waktu yang relatif banyak dalam pelaksanaanya, akan tetapi hasil belajar yang dicapai tentunya tentunya sebanding dengan waktu yang digunakan. Pengetahuan baru akan melekat lebih lama apabila siswa dilibatkan secara langsung dalam proses (Ristanto, 2010)

Model pembelajaran inkuiri terbimbing dapat lebih membiasakan siswa untuk membuktikan suatu materi pelajaran, membuktikan dengan melakukan penyelidikan sendiri oleh siswa yang dibimbing oleh guru. Penyelidikan dapat dilakukan oleh siswa baik di dalam ruangan seperti di laboratorium maupun di lapangan terbuka kemudian hasil penyelidikan dianalisis oleh para siswa menggunakan buku-buku referensi yang mendukung tentang materi yang diselidiki. Dengan menggunakan model pembelajaran inkuiri terbimbing ini pengembangan ranah kognitif siswa lebih terarah dan dalam kehidupan seharihari dapat diaplikasikan secara motorik.

Beberapa keunggulan dalam mengajar dengan menggunakan metode inkuiri terbimbing yang dikemukakan oleh Bruner (dapat dijelaskan antara lain (1) Siswa mengetahui konsep-konsep dasar dan ide-ide yang ebih baik, (2) Membantu dalam mengingat pada proses belajar yang baru, (3) Memotivasi siswa untuk berpikir dan bekerja atas inisiatif sendiri, (4) Mendorong siswa untuk berpikir intuitif dan merumuskan hipotesanya sendiri, (4) Memberikan kepusan bersifat instrinsik, (5) Proses pembelajaran yang lebih menarik.

Di samping itu metode inkuiri terbimbing juga mempunyai kelemahan yaitu (1) Kesulitan untuk mengerti tanpa suatu dasar pengetahuan faktual, pengetahuan itu secara efisien diperoleh 
Dedi Holden Simbolon \& Sahyar, Pengaruh Model Pembelajaran Inkuiri Terbimbing Berbasis Eksperimen Riil Dan Laboratorium Virtual terhadap Hasil Belajar Fisika Siswa

dengan pengajaran deduktif, (2) Ada kemungkinan hanya siswa yang pandai yang terlibat secara aktif dalam pengembangan prinsip umum dan siswa yang pasif hanya diam menunggu, (3) Memerlukan waktu yang banyak dan sering, (4) Senada dengan uraian di atas dapat disimpulkan bahwa inkuiri terbimbing merupakan pembelajaran dimana siswa memperoleh konsepkonsep dengan cara menemukan sendiri. Tujuan utama inkuiri terbimbing adalah mengembangkan keterampilan intelektual, berpikir kritis, dan mampu memecahkan masalah secara ilmiah. Langkah-langkah metode inkuiri terbimbing agar menjadi jelas dan mudah dilakukan adalah identifikasi dan klarifikasi persoalan, membuat hipotesa, mengumpulkan data, menganalisa data dan mengambil kesimpulan.

\section{Laboratorium Virtual}

UNESCO memberikan definisi "Virtual laboratory is an electronic workspace for distance collaboration and experimentation in research or other creative activity, to generate and deliver results using distributet information and comunikation technologies". Artinya laboratorium virtual adalah ruang kerja elektronik untuk berkolaborasi dan eksperimentasi dalam penelitian dan kegiatan kreatif lainnya, untuk memberikan hasil melalui dan menggunakan teknologi informasi dan komunikasi. Laboratorium virtual atau sering disebut simulasi komputer adalah alat-alat laboratorium yang dipersiapkan dalam program (software) komputer. Jadi, peralatan yang tersedia dalam kegiatan praktikum menggunakan laboratorium virtual bukan seperangkat peralatan nyata, karena peralatan yang disediakan sudah terdapat dalam software atau program tersebut, sehingga proses pembelajaran menggunakan laboratorium virtual hanya berupa simulasi.

Simulasi virtual merupakan program yang menyediakan suasana pembelajaran yang menyerupai keadaan atau fenomena yang sebenarnya. Komputer akan memberikan satu visual atau penjelasan tentang suatu situasi dan siswa berpeluang berinteraksi untuk menanggapi keadaan tersebut. Program simulasi memuat teks, grafik, animasi, bunyi dan permasalahan yang sesuai serta bermakna bagi siswa. Program jenis simulasi berguna untuk mengganti situasi yang sebenarnya yang tidak mungkin dihadirkan dalam kelas. Simulasi dalam komputer yang digunakan di dalam pembelajaran merupakan media yang sangat baik untuk meningkatkan proses belajar dengan memberikan kesempatan bagi para siswa untuk mengembangkan keterampilan di dalam mengidentifikasi masalah, mengorganisasi, menganalisis, mengevaluasi, dan mengkomunikasikan informasi. Simulasi virtual pada penelitian ini merupakan program yang membantu menyediakan suasana pembelajaran yang menyerupai keadaan atau fenomena yang sebenarnya, sehingga dapat memberikan satu visual atau penjelasan tentang suatu situasi dan siswa berinteraksi untuk menanggapi keadaan tersebut. Dalam menggunakan media komputer sebagai media pembelajaran perlu direncanakan secara sistematik, agar pembelajaran berjalan efektif. Pembelajaran menggunakan komputer perlu direncanakan dengan baik karena dapat menumbuhkan minat peserta didik, menyampaikan materi baru, melibatkan peserta didik secara aktif, mengevaluasi tingkat pemahaman siswa, dan menetapkan tindak lanjut.

Laboratorium virtual merupakan sebuah simulasi komputer yang memungkinkan fungsifungsi penting dari laboratorium riil untuk dilaksanakan pada komputer (Nugroho, 2012). Ada dua konsep utama laboratorium virtual, yaitu eksperimen riil digantikan oleh komputer sehingga eksperimen dilaksanakan dalam bentuk simulasi (eksperimen virtual) dan eksperimen laboratorium dapat digambarkan sebagai virtual ketika eksperimen tidak dikontrol oleh manipulasi langsung peralatan laboratorium, tetapi dengan alat komputer. Dalam penelitian ini, laboratorium virtual menggunakan konsep yang kedua, yaitu eksperimen yang dilakukan dengan menggunakan simulasi komputer, karena eksperimen tidak dikontrol langsung oleh peralatan laboratorium. Laboratorium virtual juga memuat 
lembar kerja siswa (LKS) yang disusun dan disajikan sedemikian rupa sesuai dengan model pembelajaran inkuiri terbimbing dan indikator yang akan diukur. Hal ini dapat membantu siswa dalam mempermudah menguasai dan memahami konsep dari materi yang diajarkan.

Virtual Laboratory merupakan situasi interaktif dan kompleks untuk memecahkan persoalan dalam bentuk simulasi secara berkelompok oleh para peneliti (Sutrisno, 2012). Laboratorium virtual yang dimanfatkan salah satunya adalah simulasi interakif PhET Colorado. PhET (Physics Education Technology) merupakan sebuah situs yang menyediakan simulasi pembelajaran fisika yang dapat di download secara gratis untuk kepentingan pengajaran di kelas atau dapat digunakan untuk kepentingan belajar individu. Simulasi interaktif PhET Colorado merupakan media simulasi interaktif yang menyenangkan dan berbasis penemuan (research based) yang berupa software dan dapat digunakan untuk memperjelas konsepkonsep fisis atau fenomena yang akan diterangkan yang merupakan ciptaan dari komunitas sains melalui PhET Project di University of Colorado, USA (Sari, Lutfi, dan Qosyim, 2013).

Kelebihan dari simulasi PhET yakni dapat melakukan percobaan secara ideal, hal ini tidak dapat dilakukan dengan menggunakn alat yang sesungguhnya. Dipilihnya simulasi PhET ini karena simulasi ini berbasis program java yang memiliki kelebihan Easy Java Simulations (EJS) dirancang khusus untuk memudahkan tugas para guru dalam membuat simulasi fisika dengan memanfaatkan komputer sesuai dengan bidang ilmunya (Rochmah dan Madlazim, 2013).

Sama seperti simulasi pada umumnya, Virtual Laboratory dimaksudkan untuk menanamkan konsep di mana proses yang harus dilakukan adalah persiapan (preparation), tampilan virtlab (performance), dan evaluasi proses eksperimen (evaluation). Sejalan dengan ini, Harms (tahun 2012) mengungkapkan bahwa "virtual laboratories, like simulations, are intended to transfer conceptual and procedural knowledge. Since this knowledge refers to the preparation, the performance and the evaluation of laboratory experiments, itis necessary to impart both background knowledge and also knowledge referring to actually carrying out the experiment". Bajpai dan Kumar, (2015) dalam penelitiannya juga menemukan bahwa virtual lab through computer simulation based method of teaching physics is emerging as one of the most powerful method of experimentation in lab.

\section{Eksperimen Riil}

Eksperimen riil adalah suatu cara di mana murid bersama-sama mengerjakan sesuatu latihan atau percobaan untuk mengetahui pengaruh atau akibat dari sesuatu aksi. Melalui eksperimen riil siswa mempelajari fakta, gejala, konsep, prinsip, hukum dan lain sebagainya. Sehingga selain memperoleh pengetahuan kognitif juga dapat keterampilan/kinerja dan dapat menerapkan pengetahuan dan keterampilan tersebut pada situasi yang baru serta memperoleh sikap ilmiah (Susiandari, 2012). Dalam eksperimen riil siswa dituntut untuk melakukan eksperimen langsung dilaboratorium sesuai dengan penuntun praktikum yang diberikan oleh guru. Setelah melakukan prosedur praktikum, mulai dari mempersiapkan alat dan bahan praktikum, melakukan prosedur kerja, melakukan pengamatan, sampai pada penarikan kesimpulan. Pada akhirnya diharapkan siswa dapat menemukan konsep yang akan dipelajarinya. Dengan pembelajaran menggunakan eksperimen riil maka siswa diharapkan dapat memperoleh pengalaman langsung lebih mudah memahami materi pelajaran yang sedang dipelajari.

\section{Hasil Belajar}

"Prestasi belajar adalah suatu bukti keberhasilan belajar atau kemampuan seseorang siswa dalam melakukan kegiatan belajarnya sesuai dengan bobot yang dicapainya". Menurut Dimyati hasil belajar adalah hasil yang ditunjukkan dari suatu 
interaksi tindak belajar dan biasanya ditunjukkan dengan nilai tes yang diberikan guru. Muhibbin menjelaskan bahwa pengungkapan hasil belajar idealnya meliputi segenap ranah psikologis yang berubah sebagai akibat pengalaman dan proses belajar siswa. Penilaian hasil belajar diharapkan mencerminkan perubahan tingkah laku, baik yang berdimensi pada cipta (kognitif), rasa (afektif), dan karsa (psikomotor) (Yuliati, Yulianti, dan Khanafiyah, 2011).

Standar penilaian pendidikan sesuai dengan Permendiknas No. 20 Tahun 2007, menjelaskan bahwa penilaian hasil belajar peserta didik pada jenjang pendidikan dasar dan menengah didasarkan pada prinsip-prinsip sebagai berikut: (1) Sahih, berarti penilaian didasarkan pada data yang mencerminkan kemampuan yang diukur; (2) Objektif, berarti penilaian didasarkan pada prosedur dan kriteria yang jelas, tidak dipengaruhi subjektivitas penilai; (3) Adil, berarti penilaian tidak menguntungkan atau merugikan peserta didik karena berkebutuhan khusus serta perbedaan latar belakang agama, suku, budaya, adat istiadat, status social ekonomi, dan gender; (4) Terpadu, berarti penilaian oleh pendidik merupakan salah satu komponen yang tak terpisahkan dari kegiatan pembelajaran; (5) Terbuka, berarti prosedur penilaian, kriteria penilaian, dan dasar pengambilan keputusan dapat diketahui oleh pihak yang berkepentingan; (6) Menyeluruh dan berkesinambungan, berarti penilaian oleh pendidik mencakup semua aspek kompetensi dengan menggunakan berbagai teknik penilaian yang sesuai, untuk memantau perkembangan kemampuan peserta didik; (7) Sistematis, berarti penilaian dilakukan secara berencana dan bertahap dengan mengikuti langkahlangkah baku; (8) Beracuan kriteria, berarti penilaian didasarkan pada ukuran pencapaian kompetensi yang ditetapkan, (9) Akuntabel, berarti penilaian dapat dipertanggungjawabkan, baik dari segi teknik, prosedur, maupun hasilnya.

Prosedur tertulis digunakan untuk mengukur hasil belajar yang bersifat kognitif dan afektif, sedangkan prosedur observasi digunakan untuk mengukur hasil belajar yang bersifat psikomotor. Penilaian prestasi belajar, perlu dilakukan terhadap keseluruhan kompetensi yang telah dipelajari peserta didik melalui kegiatan pembelajaran. Ditinjau dari dimensi kompetensi yang ingin dicapai, ranah yang perlu dinilai meliputi nanah kognitif, domain afektif, dan domain psikomotor. Dalam penelitian ini, penilaian hail belajar diukur berdasarkan ranah kognitif Taksonomi Bloom yang meliputi aspek pengetahuan dan pengenalan (C1), pemahaman $\left(C_{2}\right)$, penerapan $\left(C_{3}\right)$, analisis $\left(C_{4}\right)$, sintesis $\left(C_{5}\right)$ dan kreasi (C6).

Suatu proses belajar dikatakan berhasil baik apabila dapat menghasilkan prestasi belajar yang baik pula. Untuk mengetahui sejauh mana kegiatan belajar yang dilaksanakan dalam upaya mencapai tujuan dan target yang telah ditetapkan maka perlu adanya kegiatan evaluasi belajar. Evaluasi adalah penilaian terhadap tingkat keberhasilan siswa dalam mencapai tujuan belajar dalam sebuah program pembelajaran. Hasil dari kegiatan evaluasi tersebut dapat memberikan gambaran mengenai prestasi belajar yang dicapai. Pengukuran prestasi belajar dengan penilaian hasil belajar secara menyeluruh baik secara kualitatif maupun secara kuantitatif.

Menurut Gagne (dalam Dahar, 2011) penampilan yang dapat diamati sebagai hasil belajar disebut kemampuan (capabilities). Menurut Gagne ada lima kemampuan, yaitu keterampilan intelektual, strategi-strategi kognitif, invormasi verbal, sikap dan keterampilan motorik. Berhasilnya kegiatan belajar siswa ditentukan oleh usaha dan aktivitas siswa itu sendiri, disamping faktor kemauan, minat, ketekunan, tekad untuk sukses dan cita-cita. Hasil belajar yang tinggi dapat dicapai jika siswa berusaha secara maksimal dan menggunakan cara belajar yang benar dan efektif (Suyanti, 2010).

\section{METODE}

Penelitian ini merupakan penelitian yang bersifat eksperimen semu (Quasi Experiment) dengan 
memberikan perlakuan berupa pembelajaran. Pada penelitian ini terdapat dua kelas penelitian dengan perlakuan yang berbeda-beda, yaitu kelas eksperimen dan kelas kontrol. Kelompok eksperimen diberi model pembelajaran inkuiri terbimbing berbasis eksperimen riil dan laboratorium virtual sedangkan kelas kontrol menggunakan model pembelajaran Direct Instruction (DI).

Penelitian ini telah dilaksanakan di SMA Swasta Methodist 1 Medan pada Tahun Ajaran 2012/2013 pada semester II selama 4 bulan, yaitu bulan Februari - Mei 2013. Populasi dalam penelitian ini adalah seluruh siswa kelas XI IPA SMA Swasta Methodist 1 Medan tahun pelajaran 2012/2013 yang terdiri dari 4 kelas dengan jumlah siswa sebanyak 151 orang siswa. Sampel dibagi menjadi 2 kelas, yaitu kelas eksperimen (XI IPA - B) berjumlah 39 orang dan kelas kontrol (XI IPA - C) berjumlah 37 orang siswa. Kelompok eksperimen diberi model pembelajaran inkuiri terbimbing berbasis eksperimen riil dan laboratorium virtual sedangkan kelas kontrol menggunakan model pembelajaran Direct Instruction (DI). Dengan teknik pengambilan sampel teknik pengambilan sampel dalam penelitian ini dengan menggunakan teknik Cluster Random Sampling. Desain penelitian yang digunakan adalah penelitian eksperimen dengan pertimbangan bahwa penelitian ini berusaha untuk mengetahui pengaruh dan hubungan antara suatu variabel terhadap variabel lain.

Tabel 1 Desain Penelitian

\begin{tabular}{cccc}
\hline Group & Pre tes & Perlakuan & Pos tes \\
\hline Eksperimen & $\mathrm{X}_{1}$ & $\mathrm{P}_{1}$ & $\mathrm{X}_{2}$ \\
\hline Kelas Kontrol & $\mathrm{Y}_{1}$ & $\mathrm{P}_{2}$ & $\mathrm{Y}_{2}$ \\
\hline
\end{tabular}

Rancangan penelitian dapat disajikan dengan desain faktorial $2 \times 2$ dengan teknik analisis varians (Anova) 2 jalur seperti disajikan dalam Tabel 2.
Tabel 2 Rancangan Penelitian

\begin{tabular}{ccc}
\hline Parameter & $\begin{array}{c}\text { Kelas } \\
\text { Eksperimen } \\
\left(\mathrm{A}_{1}\right)\end{array}$ & $\begin{array}{c}\text { Kelas } \\
\text { Kontrol }\left(\mathrm{A}_{2}\right)\end{array}$ \\
\hline $\begin{array}{c}\text { Aktivitas Tinggi } \\
\left(\mathrm{B}_{1}\right)\end{array}$ & $\mathrm{A}_{1} \mathrm{~B}_{1}$ & $\mathrm{~A}_{2} \mathrm{~B}_{1}$ \\
\hline $\begin{array}{c}\text { Aktivitas } \\
\text { Rendah }\left(\mathrm{B}_{2}\right)\end{array}$ & $\mathrm{A}_{1} \mathrm{~B}_{2}$ & $\mathrm{~A}_{2} \mathrm{~B}_{2}$ \\
\hline
\end{tabular}

Variabel bebas moderator adalah variabel bebas bukan utama yang juga diamati pada penelitian untuk menentukan sejauh mana efeknya ikut memengaruhi hubungan antara variabel bebas utama dan variabel terikat. Pada penelitian ini yang menjadi variabel bebas moderator adalah tingkat aktivitas belajar fisika siswa. Tingkat aktivitas siswa meliputi segala kegiatan yang dilaksanakan baik secara jasmani maupun rohani yang mengarah pada proses belajar seperti bertanya, mengajukan pendapat, mengerjakan tugas-tugas, dapat menjawab pertanyaan guru dan bekerja sama dengan siswa lain, serta bertanggung jawab terhadap tugas yang diberikan.

Variabel terikat adalah suatu keadaan yang menunjukan pengaruh dan akibat yang disebabkan oleh variabel bebas. Variabel terikat dalam penelitian ini adalah prestasi atau hasil belajar siswa pada pelajaran fisika yaitu hasil prestasi kognitif siswa pada ranah kognitif Taksonomi Bloom.

Teknik pengumpulan data dilakukan dengan menggunakan instrumen penelitian, yaitu tes hasil belajar fisika siswa dan observasi tingkat aktivitas siswa dalam belajar fisika. Instrumen kegunaanya adalah untuk mengukur hasil belajar fisika yang disusun dalam bentuk tes objektif berupa esay dan mengukur tingkat aktivitas siswa dalam belajar fisika.

Analisis data yang dilakukan meliputi (1) Analisis untuk melihat normalitas dan homogenitas dari instrumen penelitian, (2) Analisis terhadap pengaruh model pembelajaran dengan metode pembelajaran yang disusun dalam peningkatan hasil belajar siswa, dengan cara menganalisis perbedaan antara hasil belajar pre tes dan pos tes serta tingkat aktivitas siswa, (3) Analisis terhadap data hasil tes dilakukan 
untuk melihat peningkatan hasil belajar siswa terhadap konsep dinamika fluida dengan cara mendeskripsikan data skor hasil pre tes dan post tes masing-masing siswa.

Pengujian hipotesis dilakukan untuk mengetahui apakah hipotesis yang sudah dilakukan ditolak atau diterima. Untuk menguji hipotesis dalam penelitian digunakan rumus anova dua jalan dengan desain faktorial $2 \times 2$. Tujuan analisis varian dua jalan tersebut adalah untuk menguji signifikansi efek 2 variabel bebas terhadap satu variabel terikat dan interaksi kedua variabel bebas terhadap variabel terikat.

Uji hipotesis dalam penelitian ini menggunakan analisis varians (Anava) 2 arah (Two Way Anova) pada General Linear Model (GLM) univarians dengan program SPSS 20. Pada uji hipotesis ini taraf signifikansi $(\alpha)$ ditetapkan $=$ 0,05 . Taraf signifikansi merupakan angka yang menunjukkan seberapa besar peluang terjadinya kesalahan analisis. Hipotesis statistik yang perlu diuji dalam penelitian ini adalah Tolak $\mathrm{H}_{\mathrm{o}}$, jika $\mathrm{F}_{\mathrm{A}}$ $>\mathrm{F}_{\text {tabel(dbA;dbB;0.05) }}$, dalam hal lain terima $\mathrm{H}_{0}$.

\section{Keterangan:}

Ho: Hipotesis nol, untuk parameter jika taraf signifikasi hasil pengujian atau perhitungan hipotesis statistik lebih besar dari $\mathrm{F}_{\text {tabel. }}$

Ha: Hipotesis nol, untuk parameter jika taraf signifikasi hasil pengujian atau perhitungan hipotesis statistik lebih kecil dari $\mathrm{F}_{\text {tabel. }}$

Uji gain dilakukan untuk mengetahui peningkatan hasil belajar sebelum dan sesudah pembelajaran dihitung dengan rumus gain skor ternormalisasi. Persamaan untuk perhitungan gain, disajikan dalam rumus berikut.

$$
\mathrm{g}=\frac{\mathrm{S}_{\text {pos }}-\mathrm{S}_{\text {pre }}}{\mathrm{S}_{\text {maka }}-\mathrm{S}_{\text {pre }}}
$$

Tingkat perolehan skor dikategorikan atas tiga kategori, yaitu:

- $\quad$ Tinggi: $g>0.7$

- Sedang: $0.3<\mathrm{g}<0.7$

- Rendah: $\mathrm{g}<0.3$

\section{HASIL DAN PEMBAHASAN \\ Hasil}

\section{Penyajian dan Analisis Data}

Data yang dideskripsikan pada penelitian ini meliputi data hasil belajar dan data aktivitas belajar fisika siswa pada mata pelajaran fisika di kelas XI IPA SMA Methodist-1 Medan. Hasil belajar fisika siswa merupakan nilai hasil belajar kelompok siswa yang diajar dengan menggunakan model pembelajaran Inkuiri Terbimbing berbasis eksperimen riil dan laboratorium virtual dan kelompok siswa yang diajar dengan menggunakan model pembelajarn langsung (Direct Instruction) dengan menggunakan eksperimen riil. Aktivitas belajar merupakan salah satu faktor yang dapat memengaruhi keberhasilan kegiatan belajar yang diukur dengan menggunakan observasi selama proses pembelajaran berlangsung.

\section{Deskripsi Data Hasil Belajar Siswa}

Berdasarkan data hasil penelitian berupa hasil belajar fisika yang diperoleh dari data nilai pretes, postes hasil belajar fisika siswa dan gain ternormalisasi untuk kelas DI dan kelas Inkuiri Terbimbing dirangkum dalam Tabel 3.

Tabel 3. Nilai Rata-Rata Gain Hasil Belajar Fisika Siswa Siswa Kelas DI dan Inkuiri Terbimbing pada Kategori Ranah Kognitif

\begin{tabular}{ccccccc}
\hline \multirow{2}{*}{ Model } & \multicolumn{7}{c}{ Kategori } \\
\cline { 2 - 7 } & C1 & C2 & C3 & C4 & C5 & C6 \\
\hline DI & 0.22 & 0.14 & 0.54 & 0.47 & 0.33 & 0.32 \\
Ink & 0.31 & 0.40 & 0.74 & 0.75 & 0.75 & 0.68 \\
\hline
\end{tabular}

Perolehan nilai rata-rata gain atau peningkatan hasil belajar fisika untuk kelas DI pada tingkat kognitif $\mathrm{C} 1, \mathrm{C} 2, \mathrm{C} 3, \mathrm{C} 4, \mathrm{C} 5$ dan C6 secara berurutan adalah $0.22,0.14,0.54$, $0.47,0.33$ dan 0.32 . Perolehan nilai rata-rata gain atau peningkatan hasil belajar fisika untuk kelas Inkuiri Terbimbing adalah 0.31, 0.40, 0.74, $0.75,0.75$ dan 0.68 . 
Tabel 4 Rata-Rata Nilai Pretes, Postes dan Gain Hasil Belajar Fisika

\begin{tabular}{cccc}
\hline Kelas & Pretes & Postes & Gain \\
\hline DI & 28.00 & 57.41 & 0.40 \\
\hline $\begin{array}{c}\text { Inkuiri } \\
\text { Terbimbing }\end{array}$ & 24.87 & 75.28 & 0.68 \\
\hline
\end{tabular}

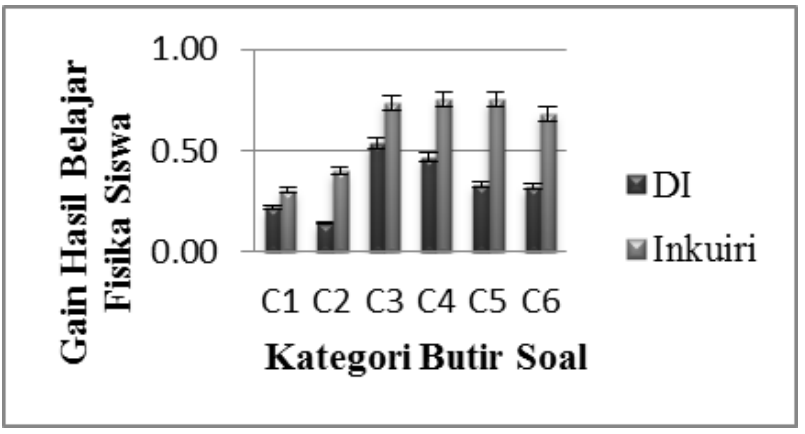

Gambar 1 Grafik Nilai Rata-Rata Gain Hasil Fisika Belajar Siswa Kelas DI dan Inkuiri Terbimbing Kategori Ranah Kognitif

Berdasarkan Tabel 4 dan Gambar 1, maka diperoleh kesimpulan bahwa untuk kategori $\mathrm{C} 1$ Inkuiri Terbimbing (kelas eksperimen) memiliki nilai rata-rata gain lebih tinggi 0.09 dibandingkan dengan DI (kelas kontrol). Untuk kategori C2 Inkuiri (kelas eksperimen) memiliki nilai rata-rata gain lebih tinggi 0.26 dibandingkan dengan DI (kelas kontrol). Untuk kategori C3 Inkuiri (kelas eksperimen) memiliki nilai rata-rata gain lebih tinggi 0.20 dibandingkan dengan DI (kelas kontrol). Untuk kategori C4 Inkuiri (kelas eksperimen) memiliki nilai rata-rata gain lebih tinggi 0.29 dibandingkan dengan DI (kelas kontrol). Untuk kategori C5 Inkuiri (kelas eksperimen) memiliki nilai rata-rata gain lebih tinggi 0.42 dibandingkan dengan DI (kelas kontrol).Untuk kategori C6 Inkuiri (kelas eksperimen) memiliki nilai rata-rata gain lebih tinggi 0.36 dibandingkan dengan DI (kelas kontrol).

Pada tingkat kognitif C1 dan C2 nilai ratarata gain atau peningkatan hasil belajar fisika lebih rendah. Hal ini menunjukkan bahwa untuk tingkat kognitif C1 dan C2 tidak perlu menggunakan model yang bervariasi karena hanya membutuhkan tingkat pemahaman dan daya ingat saja, sehingga peningkatan nilainnya juga rendah. Sedangkan untuk tingkat kognitif yang lebih tinggi seperti C3, C4, C5 dan C6 nilai rata-rata gain atau peningkatan hasil belajar fisika di setiap model jauh lebih tinggi atau lebih besar. Pada kategori C3, C4, C5 dan C6 perbedaan pencapaian nilai rata-rata gain atau peningkatan hasil belajar fisika untuk kelas DI jauh lebih kecil dibandingkan dengan kelas Inkuiri Terbimbing karena pada kelas Inkuiri Terbimbing, selama pembelajaran siswa dituntut untuk mampu menganalisis, mengevaluasi, menemukan sendiri setiap konsep atau materi yang tidak dipahami, maka ketika siswa dihadapkan pada suatu masalah atau soal yang membutuhkan daya analisis ataupun evaluasi, mereka sudah cenderung terbiasa menyelesaikannya. Dengan demikian, peningkatan nilai atau gainnya juga jauh lebih tinggi atau lebih besar. Sementara kelas DI, siswa cenderung pasif di kelas, sehingga ketika siswa dihadapkan pada soal atau masalah, hanya sebagian kecil saja yang bisa menyelesaikannya, yaitu siswa yang pada dasarnya kemiliki daya analisis yang baik.

Hal ini sejalan dengan penelitian yang dilakukan Nugroho (2012) dalam penelitiannya menemukan pembelajaran Inkuiri Terbimbing melalui labolatorium virtual dan labolatorium riil berpengaruh secara signifikan terhadap prestasi belajar kognitif, tidak berpengaruh terhadap aspek afektif. Siswa yang belajar dengan kognitif laboratorium virtual lebih baik daripada dengan laboratorium riil. Selanjutnya Kristianti (2012) dalam penelitiannya menemukan pembelajaran Inkuiri Terbimbing dengan menggunakan laboratorium riil lebih efektif dibandingkan dengan laboratorium riil.

\section{Uji Normalitas Data}

Dari hasil perhitungan uji normalitas, dapat disimpulkan bahwa data nilai gain ternormalisasi berdistribusi normal. hal ini dibuktikan dengan nilai signifikansi hasil uji menggunakan program SPSS versi 20 dengan menggunakan uji Kolmogorov-Smirnov dengan Lilliefors Significance Correction ${ }_{a}$ pada taraf signifikansi $\alpha=0.05$ yaitu $0.200>0.05$ menunjukkan bahwa 
Dedi Holden Simbolon \& Sahyar, Pengaruh Model Pembelajaran Inkuiri Terbimbing Berbasis Eksperimen Riil Dan Laboratorium Virtual terhadap Hasil Belajar Fisika Siswa

gain hasil belajar Fisika kelas eksperimen yaitu kelas yang diajar dengan menggunakan model Inkuiri Terbimbing berbasis eksperimen riil dan laboratorium virtual berasal dari populasi yang berdistribusi normal.

\section{Uji Homogenitas Data}

Dari perhitungan uji homogenitas menggunakan program SPSS versi 20 dengan menggunakan uji Lavene pada taraf signifikansi $\alpha=0.05$ bahawa nilai Signifikansi $0.042<0.05$ artinya data kelompok sampel tidak berasal dari populasi yang homogen.

\section{Uji Hipotesis}

Untuk pengujian hipotesis penelitian digunakan General Linier Model (GLM) Unvariat dengan menggunakan program SPSS versi 20 pada taraf signifikansi $\alpha=0,05$. Kelompok sampel yang diukur tingkat aktivitasnya terlebih dahulu diurutkan dari tingkat aktivitas tinggi ke rendah untuk mengklasifikasikan siswa pada kategori tingkat aktivitas tinggi dan rendah. Di mana tingkat aktivitas belajar siswa ditentukan berdasarkan nilai rata-rata dan standar deviasi masing-masing kelas.

Untuk melihat perbedaan tingkat aktivitas belajar siswa dan hasil belajar fisika siswa terhadap pembelajaran yang diberikan digunakan uji Two Way Anova dengan General Linear Model (GLM) Unvariat, sekaligus untuk melihat bagaimana pengaruh tingkat aktivitas belajar siswa terhadap hasil belajar fisikanya. Apakah siswa yang memiliki tingkat aktivitas belajar tinggi memiliki hasil belajar fisika yang tinggi pula, atau sebaliknya lebih rendah, serta apakah ada interaksi antara model pembelajaran dengan tingkat aktivitas belajar dalam memengaruhi hasil belajar fisika siswa.

Untuk melihat perbedaan hasil belajar fisika siswa dari penerapan model pembelajaran yang diberikan, digunakan uji Independent Sample $T$-tes. Secara signifikan terdapat perbedaan gain hasil belajar antara siswa yang diajar dengan menggunakan model pembelajaran Inkuiri Terbimbing berbasis eksperimen riil dan laboratorium virtual dibandingkan dengan siswa yang diajar dengan menggunakan model pembelajaran langsung (Direct Instruction). Hal tersebut ditunjukkan dengan nilai sig. 0,000< 0,05, dalam hal ini Ha diterima.

Untuk melihat perbedaan hasil belajar antara siswa yang memiliki tingkat aktivitas tinggi dan rendah, digunakan uji Independent Sample T-test. Secara signifikan terdapat perbedaan hasil belajar antara siswa yang memiliki tingakat aktivitas tinggi dan rendah. Hal tersebut ditunjukkan dengan nilai sig. 0,010< 0,05. Dalam hal ini Ho diterima.

Interaksi model pembelajaran dengan aktivitas belajar terhadap hasil belajar fisika siswa digunakan uji Two Way Anova dengan GLM Univariate. Bahwa harga signifikansi (sig) (Model*Aktivitas) adalah 0,003. Oleh karena nilai sig. 0,003 $<0,05$ maka dalam hal ini $\mathrm{Ha}$ diterima, yang berarti terdapat interaksi yang signifikan antara model pembelajaran Inkuiri Terbimbing berbasis eksperimen riil dan laboratorium virtual dengan model pembelajaran langsung $(D I)$ dengan tingkat aktivitas terhadap hasil belajar fisika siswa.

\section{Pembahasan}

Berdasarkan hasil penelitian yang dilakukan diketahui bahwa siswa yang diajar dengan menggunakan model pembelajaran Inkuiri Terbimbing berbasis eksperimen riil dan laboratorium virtual mendapatkan nilai rata-rata hasil belajar Fisika 75.28 sedangkan siswa yang diajar dengan menggunakan model pembelajaran Direct Instruction mendapatkan skor rata-rata hasil belajar fisikanya 57.41. Berdasarkan hasil dan pengujian hipotesis yang telah dilakukan diperoleh kesimpulan bahwa hasil belajar fisika siswa yang diajar dengan menggunakan model pembelajaran Inkuiri Terbimbing berbasis eksperimen riil dan laboratorium virtual dengan model pembelajaran langsung (Direct Instruction) menggunakan eksperimen riil terdapat perbedaan yang signifikan. Berdasarkan hasil uji Independent Sampel T-test yang dilakukan diperoleh bahwa harga signifikansi $0,000<0,05$ 


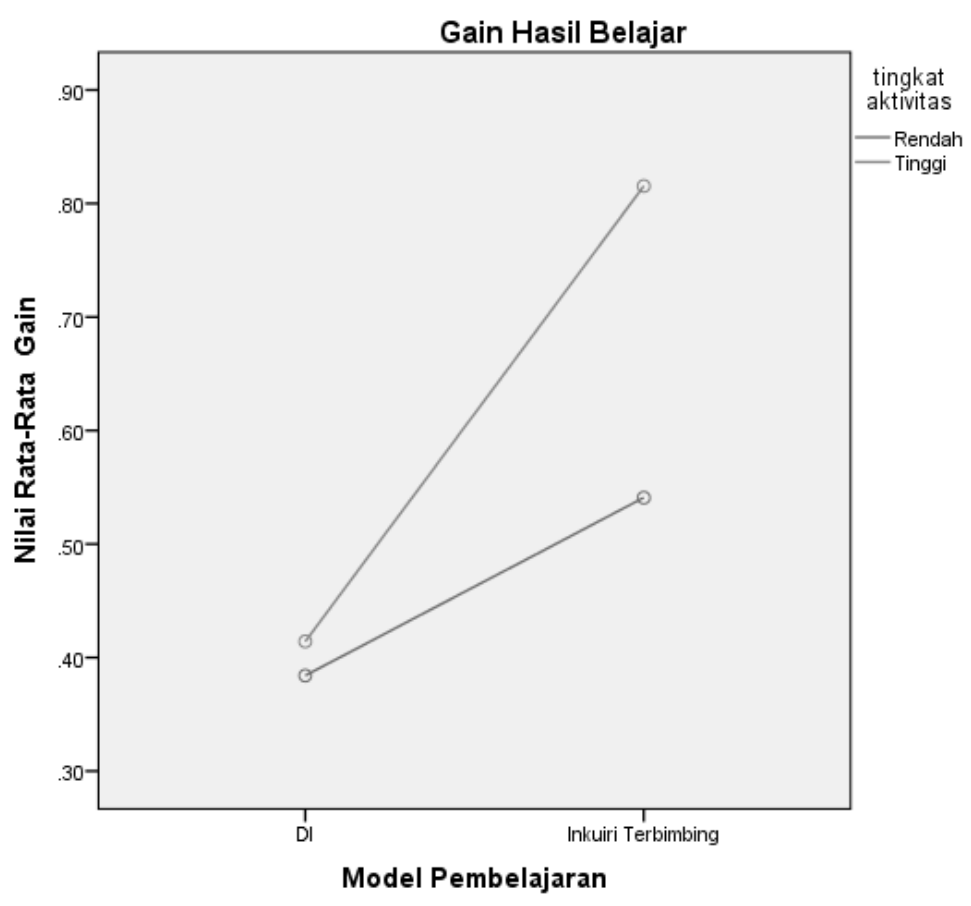

Gambar 1 Interaksi Antara Model Pembelajaran Inkuiri Terbimbing Berbasis Eksperimen Riil dan Laboratorium Virtual Dengan Model Pembelajaran Langsung (Direct Instruction) Dengan Tingkat Aktivitas Terhadap Gain Hasil Belajar Fisika Siswa

yang berarti dapat disimpulkan bahwa secara keseluruhan terdapat perbedaan yang signifikan antara peningkatan hasil belajar fisika siswa yang diajar dengan menggunakan model pembelajaran Inkuiri Terbimbing berbasis eksperimen riil dan laboratorium virtual dengan model pembelajaran langsung (Direct Instruction).

Hal ini beralasan, karena dalam pembelajaran dengan menggunakan model pembelajaran Inkuiri Terbimbing berbasis eksperimen riil dan laboratorium virtual dengan model pembelajaran langsung (Direct Instruction) dengan eksperimen riil merupakan pola pembelajaran yang memberikan pengala-man langsung kepada siswa dalam belajar karena melakukan sendiri dan juga memper-hatikan setiap variabel selama praktikum di laboratorium. Dengan menggunakan model pembelajaran Inkuiri Terbimbing berbasis eksperimen riil dan laboratorium virtual, proses pembelajaran menempatkan siswa sebagai pusat aktivitas, siswa tidak hanya mempelajari tentang sesuatu tetapi siswa secara aktif menemukan, melakukan, memperhatikan/mengamati, dan mengalami suatu aktivitas belajar. Dalam proses pembelajaran tersebut siswa menggunakan seluruh kemampuan yang dimilikinya dan yang dimiliki lingkungannya. Guru hanya berperan sebagai motivator dan fasilitator dalam mengembangkan kreativitas dan aktiitas siswa tanpa harus ada penyeragaman atau pemaksaan untuk mengikuti pemahaman guru, siswa diberikan ruang bebas untuk mewujudkan potensi dan menampilkan karakteristiknya masing-masing.

Hal ini sejalan dengan penelitian yang dilakukan TÜYSÜZ (2010) bahwa pelaksanaan praktikum dengan menggunakan laboratorium virtual lebih efektif, menarik dan lebih bermanfaat serta dapat memungkinkan siswa untuk mengulang percobaan. Sementara pada laboratorium riil tidak semua siswa aktif dalam proses eksperimen di laboratorium riil. Penelitian Nugroho (2012) dalam penelitiannya menemukan pembelajaran Inkuiri Terbimbing melalui labolatorium virtual dan labolatorium riil berpengaruh secara signifikan terhadap prestasi 
belajar kognitif, tidak berpengaruh terhadap prestasi belajar afektif. Siswa yang belajar kognitif laboratorium virtual lebih baik daripada laboratorium riil. Selanjutnya pembelajaran Inkuiri Terbimbing dengan menggunakan laboratorium virtual lebih efektif dibandingkan dengan laboratorium riil.

\section{SIMPULAN DAN SARAN}

\section{Simpulan}

Berdasarkan pengolahan data dan pembahasan hasil penelitian yang dilakukan, dapat ditarik kesimpulan sebagai berikut. Terdapat perbedaan yang signifikan antara gain hasil belajar atau peningkatan hasil belajar fisika siswa yang diajar dengan menggunakan model pembelajaran inkuiri terbimbing berbasis eksperimen riil dan laboratorium virtual dibandingkan dengan siswa yang diajar dengan menggunakan model pembelajaran langsung (Direct Instruction). Model Inkuiri Terbimbing lebih baik dari model DI dalam meningkatkan gain hasil belajar Fisika siswa. Terdapat interaksi yang signifikan antara model pembelajaran inkuiri terbimbing berbasis eksperimen riil dan laboratorium virtual dengan model pembelajaran langsung (Direct
Instruction) dalam hal tingkat aktivitas terhadap gain hasil belajar atau peningkatan hasil belajar Fisika siswa. Interaksi terjadi pada kelas DI di mana pada tingkat aktivitas tinggi dan tingkat aktivitas rendah, hasil belajarnya adalah sama yang artinya, model lebih dominan dibandingkan dengan aktivitasnya.

\section{Saran}

Sesuai dengan hasil penelitian yang didapatkan, maka disarankan sebagai berikut. Dalam pembelajaran Fisika khususnya pokok bahasan Dinamika Fluida, guru dapat menggunakan media komputer berupa laboratorium virtual untuk menggantikan praktikum yang tidak dapat dilaksanakan di sekolah. Guru hendaknya memiliki kemampuan dan pengetahuan untuk merancang pem-belajaran praktikum melalui program komputer khususnya simulasi (laboratorium virtual), sehingga dapat digunakan sebagai alat bantu dalam menstransfer materi pelajaran kepada siswa. Laboratorium virtual dapat diterapkan pada pokok bahasan yang membutuhkan praktikum untuk memberikan gambaran yang lebih jelas tentang hasil praktikum.

\section{PUSTAKA ACUAN}

Ambarsari, W., Santosa, S., \& Mariadi. 2013. Penerapan Pembelajaran Inkuiri Terbimbing Terhadap Keterampilan Proses Sains Dasar Pada Pelajaran Biologi Siswa Kelas VIII SMP Negeri 7 Surakarta. Jurnal Pendidikan Biologi, 5 (1), hlm. 81-95.

Bajpai, M, \& Kumar, A. 2015. Effect Of Virtual Laboratory On Students' Conceptual Achievement In Physics. International Journal of Current Research, 7 (2), hlm. 12808-12813.

Dahar, R.W. 2011. Teori-Teori Belajar dan Pembelajaran. Jakarta: Erlangga.

Demirdag, B. 2008. Develop A Computer Assisted Educational Materials Related to Thermochemistrym. Turkey: Institute of Educational Science.

Gerald, W. M., Harol, H., \& Mike, T. 2008. Learning Physics in a Virtual Environment: Is There Any? Journal of Physics Education, 2(2), hlm. 87-102.

Harms, U. 2012. Virtual and Remote Labs in Physics Education. Extended abstract. German Institute for Research on Distance Education at the University of Tuebingen, Konrad Adenauer-Str. 40, D-72072 Tuebingen.

Iswari, S. 2009. Pembelajaran Biologi Metode Inkuiri Terbimbing Menggunakan Lab Riil dan Lab Virtuil Ditinjau Dari Sikap IImiah Dan Gaya Belajar Siswa. Tesis. Program Pascasarjana Pendidikan Biologi. Universitas Sebelas Maret, Surakarta. 
Joyce, B., \& Weil, M. 2000. Models of Teaching. 6th Edition. America: A Pearson Education Company.

Kemdiknas. 2007. Peraturan Menteri Pendidikan Nasional Republik Indonesia Nomor 20 Tahun 2007. Jakarta: BSNP.

Kristianti, A.A. 2012. Pembelajaran IPA Dengan Inkuiri Bebas Termodifikasi Menggunakan Lab Riil Dan Lab Virtuil Ditinjau Dari Kemampuan Berpikir Dan Gaya Belajar Siswa. Tesis. Program Pascasarjana Pendidikan Fisika. Universitas Sebelas Maret, Surakarta.

Nugroho, S. 2012. Pembelajaran IPA Dengan Metode Inkuiri Terbimbing Menggunakan Laboratorium Riil Dan Virtuil Ditinjau dari Kemampuan Memori Dan Gaya Belajar Siswa. Tesis. Program Pascasarjana Pendidikan Fisika. Universitas Sebelas Maret, Surakarta.

Praptiwi, L., Sarwi, \& Handayani, L. 2012. Efektivitas Model Pembelajaran Eksperimen Inkuiri Terbimbing Berbantuan My Own Dictionary Untuk Meningkatkan Penguasaan Konsep Siswa SMP RSBI. Unnes Science Education Journal, 1(2), hlm. 86-95.

Prasetyo, U.H. 2011. Pembelajaran Fisika Dengan Inkuiri Terbimbing Menggunakan Metode Eksperimen Dan Demonstrasi Pada Lab. Virtual Ditinjau Dari Kemampuan Awal Dan Kemampuan Matematika Siswa (Studi Kasus Materi Pokok Listrik Dinamis Siswa Kelas $X$ SMA Negeri 1 Tanjung Selor Tahun Ajaran 2010/2011). Tesis. Pendidikan Sains, Program Pascasarjana, Universitas Sebelas Maret, Surakarta.

Prihatiningtyas, S., Prastowo, T., \& Jatmiko, B. 2013. Implementasi Simulasi PhET dan KIT Sederhana untuk Mengajarkan keterampilan Psikomotor Siswa pada Pokok Bahasan Alat Optik. Jurnal Pendidikan IPA Indonesia, 2(1), hlm. 18-22.

Putri, A., Syakbaniah, \& Yulkifli. 2013. Pengembangan Virtual Laboratory Pada Materi Kinematika Dengan Analisis Vektor Dalam Pembelajaran Fisika di Kelas Xi SMA. Pillar Of Physics Education, (1), h/m. 23-29.

Ristanto, R. H. 2010. Pembelajaran Berbasis Inkuiri Terbimbing Dengan Multimedia dan Lingkungan Riil Ditinjau Dari Motivasi Berprestasi dan Kemampuan Awal. Tesis. Program Pascasarjana Pendidikan Biologi. Universitas Sebelas Maret, Surakarta.

Rochmah, N. H \& Madlazim. 2013. Pengembangan Perangkat Pembelajaran Fisika Yang Bersinergi Dengan Media Lab Virtual Phet pada Materi Sub Pokok Bahasan Fluida Bergerak di MAN 2 Gresik. Jurnal Inovasi Pendidikan Fisika, 2(3), hlm. 162-166.

Rustaman, N. 2005. Strategi Belajar Mengajar Biologi. Malang: UM Press.

Sari, D. P., Lutfi, A., \& Qosyim, A. 2013. Uji Coba Pembelajaran IPA Dengan LKS Sebagai Penunjang Media Virtual Phet Untuk Melatih Keterampilan Proses Pada Materi Hukum Archimedes. Jurnal Pendidikan Sains e-Pensa, 1(2), hlm. 15-20.

Sudarmi. 2009. Model Pembelajaran Inkuiri Terbimbing Melalui Lab Riil Dan Virtuil Ditinjau Dari Gaya Belajar Dan Kemampuan Berpikir Abstrak. Tesis. PPs Pendidikan Fisika. Universitas Sebelas Maret, Surakarta.

Sugiyono. 2011. Statistika Untuk Penelitian. Bandung: Alfabeta.

Susiandari, A. 2012. Pembelajaran Fisika Berbasis Masalah Menggunakan Laboratorium Riil dan Virtual dari Kemampuan Kerja Sama dan Kemampuan Berfikir Kritis. Tesis. Program Pascasarjana Pendidikan Fisika. Universitas Sebelas Maret, Surakarta.

Sutrisno. 2012. Kreatif Mengembangkan Aktivitas Pembelajaran Berbasis TIK. Jakarta: GP Press. Suyanti, R.D. 2010. Strategi Pembelajaran Kimia. Edisi Pertama. Yogyakarta: Graha Ilmu. 
Dedi Holden Simbolon \& Sahyar, Pengaruh Model Pembelajaran Inkuiri Terbimbing Berbasis Eksperimen Riil Dan Laboratorium Virtual terhadap Hasil Belajar Fisika Siswa

Tarno. 2010. Pembelajaran Fisika Metode Eksperimen Menggunakan Laboratorium Riil dan Virtual Ditinjau dari Kemampuan Berpikir dan Kreativitas Peserta Didik: Studi Kasus di SMP Negeri 9 Surakarta Kelas VIII pada Sub Pokok Bahasan lensa Tahun Pelajaran 2008/2009. Tesis. Program Pascasarjana Pendidikan Fisika. Universitas Sebelas Maret, Surakarta.

Tatli, Z. \& Ayas, A. 2013. Effect of Virtual Chemistry Laboratory on Students' Achievement. Journal of Educational Technology and Society, 16(1), hlm. 159-170.

Tüysüz, C. 2010. The Effect of the Virtual Laboratory on Students' Achievement and Attitude in Chemistry. International Online Journal of Educational Sciences, 2(1), hlm. 37-53.

Yuliati, D.I, Yulianti, D, \& Khanafiyah, S. 2011. Pembelajaran Fisika Berbasis Hands On Activities Untuk Menumbuhkan Kemampuan Berpikir Kritis dan Meningkatkan Hasil Belajar Siswa SMP. Jurnal Pendidikan Fisika Indonesia (JPFI), 7(1), hlm. 23-27. 
Jurnal Pendidikan dan Kebudayaan, Vol. 21, Nomor 3, Desember 2015 